\title{
From littérature engagée to Engaged Translation: Staging Jean-Paul Sartre's Theatre as a Challenge to Franco's Rule in Spain
}

\author{
Catherine O’Leary \\ Department of Spanish, University of St Andrews, Scotland
}

\begin{abstract}
The practice of creating translations that 'rouse, inspire, witness, mobilize, and incite to rebellion' is described by Maria Tymoczko, following Jean-Paul Sartre's littérature engagée, as 'engaged translation' (2007, 213). In Spain, under the Franco dictatorship (1939-1975), the theatre became a site of opposition to his rule and the creation of 'engaged' translations of foreign plays was one of the ways in which alternative social and political realities were transmitted to local audiences. This was particularly evident during the so-called apertura period (1962-1969), when Spain's political leaders embraced more liberal and outwardfacing cultural policies as part of their efforts to ensure the regime's continuity. Drawing on archival evidence from the state censorship files held at Archivo General de la Administración (AGA) in Alcalá de Henares, this article considers how 'engaged' translations of Sartre's theatre were employed as instruments of cultural opposition to the Spanish dictatorship. It also argues that an analysis of the files both helps us to understand the role of censorship in shaping an official version of the past, and shines a light on the memory of a little-studied aspect of cultural activism in the Spanish theatre.
\end{abstract}

Keywords: theatre censorship; translation and censorship; Spain under Franco; JeanPaul Sartre; engaged translation 


\section{Introduction}

This article considers the role of translations of foreign drama as part of the cultural opposition to the Franco dictatorship (1939-1975). Although a minority practice, during the so-called apertura period (1962-1969) of ostensible cultural leniency, translations of foreign plays were sometimes employed to subvert and contest the values of the regime. Drawing on archival evidence from the state censorship files held at Archivo General de la Administración (AGA) in Alcalá de Henares, I aim to show how the theatre of Jean-Paul Sartre was transmitted to the Spanish public with the aim of challenging the authorities and advocating for social and political change. ${ }^{1}$ The study of this archival material allows for a revised and more complete understanding of Spanish theatre history as well as for a fuller assessment of the interplay between translation, activism and the memory of the dictatorship.

The work of those who translated Sartre for the stage during the Franco regime is an example of what has been called both 'activist' and 'engaged' translation, the latter a term inspired by Sartre's notion of littérature engagée (Tymoczko, 2010, pp. 1-22 and 2007, p. 213. In choosing foreign plays dealing with political oppression, freedom and revolutionary action, albeit distanced geographically and temporally from Spain, these translators, often working closely with practitioners, aimed to contest domestic reality (Baker, 2006, p. 105; Rundle \& Sturge, 2010, p. 4). In brief, their work had the potential to activate what Mona Baker has termed 'public narratives' of Spain's civil war and silenced opposition movements, which were familiar to the target audience (2007, p. 165). The activist translations - and performances - of foreign drama in Spain are a largely neglected aspect of Spain's theatre history. In the case of Jean-Paul Sartre, despite his own contradictions and the various readings of his works, in Spain he was identified with the opposition to the regime's values, and those who staged his plays did so in full knowledge of this fact.

\section{Censorship under Franco}

While sensitivity to the norms and conventions of the target culture are necessary in translation (Bassnett, 1998, p. 93; Tymoczko, 2009), this was complicated in the context of the Franco dictatorship, where translators and adaptors were forced to work within the constraints imposed not only by theatre directors and managers, but also by the regime.

\footnotetext{
${ }^{1}$ The censorship files consulted are held at the Ministerio de Educación, Cultura y Deporte (MECD), Archivo General de la Administración (AGA), Alcalá de Henares (Madrid). They are from the theatre censorship documents within the Culture Section, IDD (03) 046.000. All further references to censorship materials are from this archive and are listed by folder (SIG) and file number.
} 
Theatre was subject to harsh censorship, on putative moral, religious and political grounds that promised to protect Spain from internal and external threats, and to limit the presentation of alternative visions of society and identity. ${ }^{2}$ While the Catholic Church's influence diminished over time, it did not disappear and the regime's censorship reflected its Nationalist-Catholic ideology (Abellán, 1989, p. 323).

Censorship legislation was introduced in 1939 and revised and amplified with the introduction of specific rules regarding cinema in 1963, which were then applied to the theatre in $1964 .^{3}$ Those wishing to stage a play had to apply for permission to do so and, from 1964, a censorship board considered the work before delivering a verdict (prohibition; authorization with cuts; or authorization in whole). In addition to the playtext, costume and set design were monitored for breaches of the law, and the verdict had to stipulate audience age and whether or not the play could be broadcast. A plenary meeting of the board was held if the initial committee of usually three censors did not reach unanimous agreement, or if the minister chose to convene it.

The 1964 theatre legislation, introduced by Minister Manuel Fraga, was part of the socalled apertura phase (1962-1969) of social reform. Despite its liberalising pretensions, the new law prohibited, amongst other things, the justification of suicide, mercy killings, revenge, duelling, divorce, adultery, illicit sexual relations and prostitution; attacks on the family or marriage; brutality, sexual perversions, blasphemy, pornography and subversion; offensive language and images or allusions which might provoke base passions. In addition, the moral consequences of evil were to be portrayed. It is easy to see why the work of JeanPaul Sartre might cause unease amongst the censors tasked with implementing such norms. Yet, the legislation also highlights one of the other problems facing both censor and censored: many of the terms used were vague and open to interpretation.

The emergence of overtly political translations in Spain, including of Sartre's theatre, coincided with this apertura period, which also saw the continued growth of independent and experimental theatre groups and increased opposition to the regime. The response to foreign

\footnotetext{
${ }^{2}$ For further information about theatre censorship in Spain, see O’Connor (1966); Abellán (1980); Muñoz Cáliz (2005); O'Leary (2005). For information on the censorship of foreign dramatists in particular, see MerinoÁlvarez's TRACE project (www.ehu.es/trace) and Vandaele (2010).

${ }^{3}$ See Orden 15 julio 1939 and Orden 9 febrero 1963, applied to the theatre the following year by the Orden 6 febrero 1964 (MIT), por la que se aprueba el Reglamento de Régimen Interior de la Junta de Censura de Obras Teatrales y las normas de censura. In fact, there was another layer to theatre censorship - the control of publications - which was regulated by different legislation, the 1938 Press Law and its replacement in the apertura period, the 1966 Press Law. For an overview of theatre censorship in Spain in the period, see Abellán (1980) and Thompson (2012).
} 
drama depended not only on the type of play presented, but also on the reputations of the original author, the translator, and those associated with the proposed production. In the context of social and political theatre, both applicants and censors attempted to control how the play - and its message - would be delivered to, and interpreted by, the Spanish public. The files show how each side tried to take advantage of this ostensible liberalisation to its own advantage. We see an increased number of applications to stage political drama, on the one hand, and the regime's attempts to enhance its reputation by managing such performances, on the other. A feature of the 1964 legislation was the creation of the verdict of authorization for teatros de cámara (minority club theatres) only, or for a limited period (usually one night or three). This was an opportunity for university and independent theatres to stage foreign and political dramas, yet it also allowed the regime to claim liberal credentials and dismiss arguments about dictatorship by citing their authorisation, while at the same time severely limiting the public who could access them. Indeed, José María García Escudero, two-time Director General of Cinema and Theatre, stated this bluntly when he suggested in 1966 that 'con un punto de vista estrictamente político, lo aconsejable sería quitar hierro a la subversión, convertirla de oposición salvaje en oposición civilizada, metiéndola en los Teatros Nacionales' (1978, p. 191) (from a strictly political point of view, it would be advisable to weaken the subversion, turning it from savage opposition to civilized opposition, by putting it in the National Theatres).

Tymoczko tells us that translation has been a tool to express forbidden topics in a given culture because it 'is often less controlled than cultural production from within a culture itself', and we see this position reflected in comments made by censors, who often allowed for negative portraits of political leaders in foreign drama because of its geographical and historical distance from Spain (2009, p. 26). Yet it is also the case that Sartre's work tended to be accepted by censors during a time when they assumed a pragmatic political decision based on the regime's own desire to be seen as liberal and progressive. The early days of the regime had in fact reflected a xenophobic attitude towards the foreign, as the regime sought to consolidate a national identity based on Spanish National-Catholicism. Therefore, Michelle Woods's suggestion that translations may be targeted 'because they tend to challenge the "natural" or normative order of things' (2012, p. 3), is also pertinent and, in the case of Sartre, helps to explain why his work was initially prohibited in Spain (Zatlin, p. 110), when his moral and political vision was interpreted as a threat to the regime's values and identity-building efforts. 
Thus, the censors' responses to Jean-Paul Sartre changed over time in line with the regime's shifting needs and outlook. Even though eventually allowed when it suited the regime's own propaganda, restrictions on where his plays could be staged and the public they could be presented to still continued. Much of what might be termed politically, socially or morally challenging to the values of the regime was introduced via the teatros de cámara. Many of the directors who helped to advance new ideas - both theatrical and political - in the Spanish stage throughout the dictatorship came up from the ranks of university, club, and other independent theatre groups. Indeed, the state censorship files are interesting for what they reveal about the struggles within the regime to limit damage to its reputation, while striving to give an outward appearance of liberalisation. This tension was exploited by some of the regime's opponents, who saw an opportunity to say the unsayable using the words of others.

\section{Sartre as Political Proxy}

The choice of Jean-Paul Sartre's theatre would seem an obvious one for those seeking to use translation to transmit a vision of an alternative social and political order. After all, despite some contradictions and mercurial shifts in stance (see Adorno, 1977; Baker, 2003; Goldmann, 1970; Stoekle, 2003), Sartre remained a committed writer, linked in the public mind (both in Spain and in France) with political militancy and challenges to authority. He was an outspoken public intellectual, associated with the Resistance (though never a member), who attacked the bourgeoisie (thereby rejecting his own roots), denounced French colonial rule and argued for Algerian independence, participated in protests against the state in May 1968 and, more problematically, defended Stalin long after many others moved away from such a position. As Francois Bondy tells us

From Sartre's many political writings, speeches, interviews, appeals, leading articles, analyses, and from their many variations, apparent contradictions, self-refutations and changes, a relatively simple basic pattern never fails to emerge: social change must be comprehensive and revolutionary. (1967, p. 27)

Sartre's demand for a literature of commitment in Qu'est-ce que la literature? (1976 [1948]) spoke to cultural activists in Spain who, like the Frenchman, wished to turn words into action. His theatre too, fits with his ideas about engaged literature and Margot Morgan, for her part, declares that Sartre employed his political theatre 'as a tool of resistance' (2013, p. p. 88). 
While Pucciani could write in 1961 that 'Sartre's existentialism belongs for many to the war years' (p. 19), this was not the case in Spain, where the message still spoke to a significant section of a society living under a dictatorship that continued long beyond WWII. His plays engaged with issues such as freedom and choice, oppression and torture, political commitment, morality and racism (2005). It is unsurprising, therefore, that opponents of the Franco regime saw in the figure of Sartre and his work a perfect proxy for the political actions and words that were censored at home.

The state censorship files reveal that the censors also saw his work as embodying an identity that was at odds with the moral and political position of Francoism. As a regime that identified itself as Catholic, as well as Nationalist, Sartre's rejection of Catholic morality placed him in direct opposition to its values, and the reports on his theatre generally comment on his atheism and negative attitude towards religion. For example, Fr Cea's 1968 report on Les mouches (a version of a Greek tragedy, focusing on Orestes's murder of his mother, Clytemnestra and her husband, the tyrannical leader, Aegisthus, in revenge for the killing of his father, Agamemnon) refers to 'the Sartrian doctrine of religious alienation' and suggests that although the play is less crude than some of his other dramas, 'it remains false and atheist'. ${ }^{4}$ The fact that all of his works (both past and any future ones) were placed on the Vatican's Index Librorum Prohibitorum in 1948 (Cox, 2016, pp. 159-60), was proof, if the censors needed it, of the Frenchman's degeneracy and bad influence, a justification mentioned directly in several censors' reports. ${ }^{5}$ They perceived depravity most obviously in his lesbian and nymphomaniac characters, such as Inez and Estelle in Huis clos (which presents the hellish situation of being trapped in eternal consequences of one's actions and others' judgement of them), and in the incestuous love of Léni for her brother Frantz in Les Séquestrés d'Altona. The immorality that did not seem to concern them, however, was the ethical failure of authorities that torture, and of those who support them.

In terms of politics, the censors saw evidence of Sartre's alternative ideology in his plays and were clearly uneasy about its potential impact. In the file on the application to stage Les mouches in the Teatro Reina Victoria in 1968, the censor Elorriaga shows alarm at the danger inherent in a play to be staged in Francoist Spain that asks the question, 'Is it legitimate to kill the tyrant? ${ }^{6}$ The Adolfo Marsillach and Nuria Espert production of $L a$ putain respectueuse (dealing with race and class relations in the United States, and a

\footnotetext{
${ }^{4}$ SIG 73/9689. File 409/68. The translations from the censorship files are mine throughout.

${ }^{5}$ On Huis clos in 1964, SIG 73/9489 File 250/64; and again in 1967, SIG 73/9593 File 125/67.

${ }^{6}$ SIG 73/9689. File 409/68.
} 
denunciation of the abuse of power by members of the establishment) for the Poliorama in Barcelona the year before, is interesting also for their attempt to include some text by Simone de Beauvoir at the beginning of the performance when it moved to Madrid. ${ }^{7}$ This was interpreted as a political act, while the plays themselves (both La putain and Huis clos) were interpreted both as sufficiently distanced from Spain and as classics of the international stage. José María Ortiz, the Head of the Theatre Section, feared that the addition of what he termed a dramatized reading would turn every performance into 'a pro-communist meeting'.

The values associated with Sartre's theatre were at odds with those of the regime, therefore, in religious, moral and political terms.

\section{Who staged Sartre?}

While foreign drama was not a new phenomenon in Spain and there was an established tradition of translations, rewritings and adaptations in the decades preceding the dictatorship, most of this was neither experimental nor political. During the dictatorship itself, translations of foreign drama were employed in a variety of ways (as neutral, censoring, or politically activist) to shape and present a public narrative about Spanish identity and the regime. As Tymoczko argues, 'a translator's sensitivity to norms, especially when intuitive or subconscious, can easily slide into being (often unconsciously) submissive to and collusive with dominant cultural norms (especially those of the target culture)' (2009, p. 37). Hence, through a combination of coercive pressure and conscious or unconscious self-regulation, much of the foreign drama presented to the censorship offices reflected, or did not contest, the official values of the regime.

There were many who adapted foreign works to what they perceived was possible to stage in Spain, a perception that was shaped by the values imposed by the regime; others, such as Nicolás González Ruiz and José María Pemán, deliberately cut and shaped classical foreign drama to fit in with the regime's new narrative (see Santiago Muñoz, 2006; Gregor, 2010; García Ruiz, 2013;). It is, therefore, only a small group of Spanish translators and a small number of plays that could be described as activist in the sense of deliberately disruptive. Yet, this minority practice was a significant one in the history of Spanish theatre and involved several groups and figures whose influence on the shaping of post-war and post-dictatorship Spanish theatre is undeniable. Unsurprisingly, given the rise in student opposition to the regime in the 1960s, Sartre's dramas were popular with student theatre

\footnotetext{
${ }^{7}$ SIG 73/9602. File 189/67.
} 
groups, which despite their reliance on state funding, often took issue with censorship and sought to stage committed theatre that spoke to current social issues (See Huerta Calvo, 2018). As Preston claims, 'student agitation had been intermittent since 1956 and virtually continuous since 1962' (p. 11). In the late 1960s, and the early 1970s in particular, there are several applications from student groups to stage the works of Sartre. ${ }^{8}$ Sergio Rodríguez Tejada comments on how cultural references became a sort of shorthand for a community of opposition to the regime that was building within the university campuses: 'the student movement expressly vindicated any cultural reference -from critical intellectuals to new youth icons- sidelined by the narrow canon of the dictatorship, and therefore [...] could use them as passwords or symbolic identifiers that help them to recognize each other in a reliable way' $(2015$, p. 88$){ }^{9}$

The files also show that the censors were aware of this and sought to mitigate the impact of Sartre's (and the translators') message with restrictions on productions. For example, the files relating to an application from Carlos Álvarez Sánchez in 1967 to stage Morts sans sépulture in Santander in May by students of the Escuela Superior de Bellas Artes San Fernando reveal the censors' concerns about the notoriety of Sartre and are also interesting for what they reveal about their determination to distance the play from circumstances in Spain. The drama, set in Vichy France, depicts the choices faced by victims of torture; in Spain in the late 1960s, where repressive police measures were taken against protesting workers and students, this had a particular resonance (Preston, p. 11). Censor Bautista de la Torre declared that unless there were special measures in place to ban the author (which he assumes there are not these days, given that almost all of Brecht's work has been authorised), he saw no reason to ban it, but thought it should be restricted to teatros de cámara with monitoring of the dress rehearsal to ensure that neither the location of the play nor the set were suggestive of Spain. It was approved with those conditions.

Independent theatre groups were also attracted to what Sartre's theatre could offer. Unlike the student groups, they could not rely on state funding and are generally associated with formal experimentation, as well as social commitment, and many of these groups embraced foreign ideas about both. For Alberto Fernández Torres, 'they constituted a

\footnotetext{
${ }^{8}$ Various applications from student groups to stage Morts sans sépulture (Muertos sin sepultura) in the late 1960s and 1970s, for example, were approved with audience restrictions (See SIG 73/9596. File 150/67). Later, in 1973, applications came from La ratonera (Granada) La putain (La mujerzuela respectuosa), SIG 73/10020 File 180/73; and from student residence Colegio Mayor Navacerrada (Madrid) Les mouches (Las moscas), SIG 73/10017 File 143/73.

${ }^{9}$ For more on the importance of student theatre in the opposition to the regime, see Alberto Castilla (1999).
} 
movement that was clearly perceived as opposed to the regime.' ${ }^{10}$ The influential experimental group 'Gogo' applied to stage Les Séquestrés d'Altona at the Instituto de Estudios Norteamericanos (a location described by Ordóñez as 'free territory', presumably because it was not controlled by, or dependent on, the state) in Barcelona in $1966 .{ }^{11}$ In the end it is unclear what happened - a note in the file suggests that it was suspended pending a verdict from the Director General, but there is no further documentation in the file and no record of staging. The fact that the application had to be viewed by someone so senior suggests that the censors were wary of approving it. Other independent groups who staged Sartre's theatre included the Teatre Experimental Català and the Teatre Experimental Independent de Girona, both of which staged Les mains sales in 1967 and 1972 respectively (this is a play that depicts the debate about the revolutionary end justifying the violent means, but which was condemned by the Communists in France when first staged and later withdrawn by Sartre for many years). ${ }^{12}$ The Adrià Gual Company with Ricard Salvat at the helm, which staged Les mouches in Barcelona in 1968, was one of the most important independent groups in Spain and staged many foreign works. Indeed, in terms of the Catalan productions, Callen's claim that 'it is impossible to separate the Independent sector's implacable opposition to established cultural structures from their concept of the theatre as an instrument of socio-political struggle' (p. 25) is convincing.

As the decade progressed and the regime's apertura allowed for the staging of Sartre's dramas, some of the most important productions of his theatre in Spain came from more established, commercial companies that brought his plays and his values to a much wider audience. The theatre practitioners involved included the playwright Alfonso Sastre (in his capacity as translator of Sartre's language and message), directors Adolfo Marsillach and José María del Quinto, and actor and company director, Nuria Espert, all of whom were associated with using the stage as a space for experimentation and provocation. ${ }^{13}$

\footnotetext{
${ }^{10} \mathrm{El}$ teatro independiente en España 1962-1980. http://teatro-independiente.mcu.es/index.php. See also Fernández Torres, A. (Coord.) (1987). Documentos sobre el Teatro Independiente Español. Madrid: CNNTE. ${ }^{11}$ SIG 73/9538. File 108/66.

12 SIG 73/9576. File 5/67; SIG 73/9934. File 213/72.

${ }^{13}$ Alfonso Sastre and José María del Quinto had a long association which included the Grupo de Teatro Realista (GTR) in 1960, one of whose goals was the 'liquidation' of censorship (Martínez Michel, p. 58). In the obituary published in El pais on 26 September 2005, Eduardo Haro Tecglen described Del Quinto as 'un revolucionario del teatro'. Online. https://elpais.com/diario/2005/09/26/agenda/1127685607 850215.html Marsillach was involved in some of the most scandalous and successful theatre productions of the dictatorship, including a production of Peter Weiss's Marat-Sade in 1968 (in fact Sastre was responsible for that adaptation also). Espert was one of Spain's most successful actresses and leveraged her influence to stage social and political works by dramatists such as Brecht.
} 
Overall, then, in student, independent and mainstream theatres, the translations of Sartre's works and the values associated with the playwright himself were employed to frame a discussion about freedom, oppression and choice in Spain. By staging his works in the 1960s, they wished to draw on Sartre's notoriety, to foreground his alternative social and political philosophy, and to exploit the weakness of the regime with regard to reputation.

\section{Sartre's Translators}

An analysis of the translation of Sartre's theatre for performance in Spain is revealing both of the invisibility of translation at times, and of its importance as a tool of cultural and political activism at others.

The censorship files show that the application for staging a foreign play was supposed to name the translator involved. In several of the files, however, this information is absent. We can speculate that this indicates where the theatre group - often a university or independent group - was probably using an already published translation and did not consider the role of the translator an important one in the process of staging the play. This was probably the case, for example, with the December 1964 application by Teatro de cámara 'El Candil', in Talavera de la Reina to stage Huis clos and for the application by Instituto Vascongado de Cultura Hispánica to stage the same play in August 1966. ${ }^{14}$ More surprisingly, even where the translation is criticised, as in the report by the censor, Bautista de la Torre, on the Ateneo de Oviedo's application to stage Huis clos in 1968, its author is not always named. ${ }^{15}$

The Teatro de Camara y Ensayo 'Antorcha' in Guadalajara applied to stage Huis clos in 1966 and listed no translator. When the same company applied again in 1973, they were asked to specify the version they were using. ${ }^{16}$ The response, that it was a translation by Aurora Bernárdez, tells us that it was the Losada edition, published in Buenos Aires. ${ }^{17}$ The Losada translation is also mentioned in the application from the independent theatre group, Gogo, to stage Les Séquestrés d'Altona in $1966 .{ }^{18}$ This is evidence of another trend in Spain under Franco: the use of existing translations, rather than the commissioning of a new one. What is interesting about this is that the translations had already been done by people working in a different political context in advance of their submission to the Spanish censors.

\footnotetext{
${ }^{14}$ Both in SIG 73/9489 File 250/64.

${ }^{15}$ SIG 73/9489 File 250/64.

${ }^{16}$ SIG 73/9593 File 125/67; a new file is opened because of the new version: SIG 73/10058; File 562/73

${ }^{17}$ The first edition was published there in 1948, and a second edition (the one used here) came out in 1950.

${ }^{18}$ SIG 73/9538. File 108/66. De Asturias's 1946 novel, El Señor Presidente, is a denunciation of dictatorship.
} 
In this case, the translators on the form were listed as the Guatemalan writer Miguel Ángel Asturias and his Argentinian wife, Blanca, who produced the version published by Losada in 1961 (Sartre, 1961). A comparison of this published version with Sartre's text (2005, pp. 857-993), shows that it is faithful to the original and, given that it was not prepared for Spain, there are no insertions or deletions related to the dictatorship in the translation. While versions such as this one were not created for the particular political moment in Spain, in the case of those published by Losada, they nonetheless tended to be produced by translators sympathetic to left-wing politics. This was a company, founded by the Spaniard Gonzalo Losada and his countryman and fellow exile Guillermo de Torre, known for its publications not only of world literature, but also of many exiled Spanish writers (Larraz, 2016). Losada's choice of texts can be viewed as a statement of their cultural and political views and this story of exile and intellectual alliances is also, therefore, part of the history of Spanish theatre and translation.

Another form of cultural activism, linked to the works of Sartre, relates to the production of minority language translations of his plays. An initial ban and later severe restrictions on the staging of regional language plays, including versions of foreign works, meant that the development of Catalan, Basque and Galician-language theatre was stunted for many years (London, 1997; Callen, 1996); it also meant that those who were involved in such translation work for the theatre tended to have an activist's zeal in their determination to struggle against the odds to bring outside influence and ideas onto the stage. The apertura period brought about a boom in Catalan translations, for example, although these still had to be processed through the central censorship system in Madrid (Saumell 1996, p.104; Godayol 2016, p.59). Unlike in the case of the Castilian language, there were no existing Catalan translations of the plays, so an opportunity arose to create versions that engaged in some way with the political circumstances.

Of the translators of Sartre's theatre into Catalan, Manuel de Pedrolo, himself a playwright and author, was the most important. In his case, the translations he produced coincided with censorship of his own work (George \& London, p. 84). This suggests both that there may have been a financial motivation for the translations (Godayol, 2018) and that translating the works of an author such as Jean-Paul Sartre gave him a voice when his own was silenced. ${ }^{19}$

\footnotetext{
${ }^{19}$ On Pedrolo, see Pijuan Vallverdú (2005) and Godayol (2018), and the censorship of his work, see http://www.fundaciopedrolo.cat/?seccio=ped-Censura.
} 
It was Pedrolo's translations, published by Aymà, which were used by Ricardo Salvat of the influential Adrià Gual Company in his 1968 production of Les mouches, and by the María Rosa Roig company to stage Huis clos and La putain in $1969 .{ }^{20}$ It is worth noting that the practitioners involved in staging these translated works were also interested in social and political engagement.

The files on Les mouches reveal some of the inconsistencies and opportunities that arose when dealing with minority language translations. We know that at least one of the censors, Florentino Soria, was not actually judging the Catalan version of the play, as he mentions that he knows the Losada translation and that he cannot comment on the fidelity of the Catalan one. The fact that he was not evaluating the Pedrolo translation suggests that insertions or omissions in the Catalan version might not have been picked up by the censors. A Catalan rendering of Les mains sales, again by Manuel de Pedrolo, was the subject of an application in March from the Teatre Experimental Independent de Girona group for staging in May throughout the province and was authorised without cuts. ${ }^{21}$

The other Catalan translator whose name appears in the files is Buenaventura Vallespinosa, who produced a version of Les mains sales, which was the subject of an application from the Teatre Experimental Català to stage it in the Teatro Romea de Barcelona, in $1967 .^{22}$ Vallespinosa, a medical doctor by profession, was a significant figure in Catalan culture through his work in translating important literary (usually theatrical) texts from French and Italian (Fontcuberta i Famadas, 2005). Writing about Catalan translators more generally, Godayol (2018) suggests that they tended to be Catalan-language authors themselves and were motivated by a combination of financial need and a desire to promote literature in that language.

The latter motive is also clear in the creation of a Galician translation of La putain respectueuse. The translator was the respected intellectual, co-founder of Editorial Galaxia, and later President of the Real Academia Galega, Francisco Fernández del Riego, whose life's work was dedicated to the promotion of Galician culture (Salgado, 2010). The Teatro Popular Gallego from Vigo applied to stage the play at the Teatro García Barbón in February 1968. It was authorised for over 18s, with cuts - generally bad language, which the censors claimed was more extreme in Galician than in Castilian. The comments of one of the censors,

\footnotetext{
${ }^{20}$ Les mosques SIG 73/9627. File 365/67 - the application is dated December 1967; A porta tancada SIG 73/9709 File 148-69; La p... respectuosa SIG 73/9705. File 111/69.

${ }^{21}$ SIG 73/9934. File 213/72. During the transition period, his version of Morts sin sepultura was staged in 1976 (SIG 73/10190. File 1341/76).

${ }^{22}$ SIG 73/9576. File 5/67.
} 
Elorriaga Fernández, however, also suggest that there were some insertions as the text was translated and that these were negative allusions to religion. ${ }^{23}$ Overall, the activism involved in minority-language translations of Sartre have much to do with the promotion of an identity that was at odds with the centralising National-Catholicism imposed by the regime.

From the point of view of activist translation, however, the most prolific and important figure is undoubtedly the political playwright (and almost namesake) Alfonso Sastre, who was also Jean-Paul Sartre's representative in Spain (a fact that suggests that the Frenchman was satisfied with the Spaniard's politics and intentions). For Luciano García Lorenzo, Sastre's own theatre, with its focus on 'pain, violence, death, anguish, blood and frustrations' is a denunciation of an unjust society that he was determined to change (1975, pp. 136-37). ${ }^{24}$ Between 1967, when Sartre was first authorised for the commercial stage, and 1970, Sastre was responsible for eight translations of Sartre's plays. The censorship files demonstrate the censors' awareness, not only of the dangers of staging Sartre's work but also the impact of Alfonso Sastre as translator. As a dramatist himself, Sastre ran into trouble with the authorities, and his translation of the works of Sartre, as in the case of Pedrolo, coincided with increasing difficulties getting his own plays past the censors' scrutiny (see MartínezMichel, 2003 and O'Leary, 2004). His choice to stage Sartre's theatre at a time of heightened student protest and unrest clearly exemplifies theatre translation as political activism.

The first application to stage Huis clos on the commercial stage came from Teatro de la Comedia (Madrid) in 1967 and used Sastre's translation. ${ }^{25}$ One of the conditions of authorisation was the change of title from El infierno (Hell), presumably for religious reasons, to A puerta cerrada (Behind closed doors). It had already been approved with this title for cámara and been published with this title by Losada. This change was accepted by both Sartre and Sastre. Following a plenary session of the censorship board, it was eventually authorised for over 18s, with cuts to eliminate the word 'cabrón' (bastard) and a stipulation that the dress rehearsal be monitored, a common practice that generally sought to catch any politicised insertions or suggestions of a Spanish context, or, as in this case, to ensure that lewdness was avoided in the staging.

In June 1967, the Teatro de la Comedia applied to stage the Alfonso Sastre's version of La putain respectueuse, and it was authorised for over $18 \mathrm{~s}$ with several cuts, all referring

\footnotetext{
${ }^{23}$ SIG 73/9638. File 47/68. The published translation referred to in the application was completed in 1951.

${ }^{24}$ For further analyses of Sastre's social and political theatre, see De Paco (1993); Gies (1975); Pasquariello (1965-66); Forest (1997); and Sastre's own essays, Drama y sociedad (1956); Anatomía del realismo (1965); and La revolución y la crítica de la cultura (1970).

${ }^{25}$ SIG 73/9593. File 125/67.
} 
to sexually explicit language and bad taste. ${ }^{26}$ The verdict makes clear that the title of the play could not be used and was instead to be called 'Respetuosa'. Sastre's versions of La putain and Huis clos were also employed for a production in Barcelona in 1968 by Nuria Espert, Gemma Cuervo and Fernando Guillen, with Adolfo Marsillach as director. ${ }^{27}$ This combination of translator, actors and director was a clear indication of the production as a political event. It was approved with a single cut and review of dress rehearsal but, as already mentioned, a subsequent request to include some text by Simone de Beauvoir to be recited before the start of the play was prohibited for political reasons.

Within the file on the application from the Justo Alonso Company in December 1967 to stage Morts sans sépulture in March 1968 in the Teatro Barcelona, initial reports suggest that the play should be limited to cámara performances. ${ }^{28}$ Debarati Sanyal notes that when first staged in 1947, the play 'shocked audiences by portraying the torture of resistance fighters by the French military police' (2010, p. 67). As she points out, Sartre accuses the French: 'Once horrified by the atrocities committed by the Nazis, the French public has imperceptibly slipped into their footsteps' (p. 69). This too, in the late 1960s, was a message to the public in Spain at a time when the regime was engaged in brutal repression of student and worker protests. The censor Soria's report is the most insightful reading of the motivations behind the attempt to stage this play. He cautioned that the political affiliations of both author and (significantly) translator must be considered, and he sounded a warning about the drama's political content and parallels with Spain. Not only did he point to the play's justification of both murder and suicide, but also noted the similarity between the suicide depicted on stage and a similar defenestration in Spain, and the representation of the resistance (associated with the Communist Party) as heroes and the government as cruel. ${ }^{29}$ The result was that although the application from the Justo Alonso company was for a commercial production, it was only authorised for cámara.

The failure to secure commercial authorization led to a further application in February 1968 by the same company to stage the play in the Teatro Reina Victoria in Madrid. Given Jean-Paul Sartre's widely-reported support for student protests, Alfonso Sastre's reputation as

\footnotetext{
${ }^{26}$ SIG 73/9602. File 189/67.

${ }^{27}$ SIG 73/9602. File 189/67; SIG 73/9593 File 125/67.

${ }^{28}$ SIG 73/9627. File 363/67.

${ }^{29}$ It is not specified in the file but is likely to refer to the defenestration of Communist leader, Julián Grimau during interrogation following his arrest in 1962 by the political police force, the Brigada Político Social. He did not die and was executed by the regime in 1963. Indeed, Sartre condemned the killing in an article called 'Grimau', published in Libération on 27-28 April 1963, a week after the execution (see Contat \& Rybalka and McCleary, 1974, p. 434).
} 
a thorn in the side of the regime, and the ongoing clashes between students, workers and authorities in Spain, this version of a play about state torture was clearly intended to address the political situation in Spain. ${ }^{30}$ The initial censors were reluctant to judge the play in the prevailing political circumstances, and all commented on the high obscenity count in the translation. A note in the file tells us that this is a version approved by Sartre himself, who was obviously not bothered by Sastre's colourful language. It went to a plenary of the censorship board.

Several of the censors, aware of the fame of the author, advocated a series of cuts and audience restrictions. Some suggested prohibition because of the political content, and others opted again for the pragmatic option of prohibition for the commercial stage, where it would have more influence, coupled with authorization for minority audiences. In the end it was authorised for over 18s, with cuts on 12 pages. Moreover, it was not authorised for broadcast, and the dress rehearsal was to be closely monitored to ensure that staging highlighted its temporal and geographical distance from current Spanish circumstances.

In terms of comparison between the original French and the Spanish version, we see here, as in others completed by Alfonso Sastre, a fairly faithful translation in terms of the action of the drama, although there is, at times, a tendency to more provocatively bawdy language in the Spanish version than in the French. This could be seen as in keeping with Sastre's own lexicon and style, and also as updating the vocabulary for the 1960s (often student or independent) productions he was involved with. In his report on Sastre's 1968 version of Morts sans sépulture, Fr Artola helpfully listed his objections, amongst them the use of words such as 'jodido' (fucked); 'putilla' (slut); 'cabrones' (bastards); 'me cago en' (I shit on...); 'coño' (cunt, not as strong in Spanish as in English); and 'mierda' (shit). The censor, Aragonés, also points to Sastre's tendency to add to or augment the obscenity in the original; he summarised what he saw as the problem as follows:

Traducción de la obra de Sartre, fiel en su desarrollo y no tanto en los diálogos, en los que Sastre incorpora palabras y frases coloquiales de grueso calibre en traducción libérrima (Translation of the work of Sartre, faithful in its development and not so much in the dialogues, in which Sastre incorporates colloquial and coarse phrases in a free translation). ${ }^{31}$ A year later, in December 1968, Manuel Collado applied on behalf of the María José Goyanes - Emilio Gutiérrez Caba theatre company to stage Les mouches in Madrid's Teatro

\footnotetext{
${ }^{30}$ SIG 73/9641. File 76/68.

31 SIG 73/9641. File 76/68.
} 
Reina Victoria the following April. The translation was again prepared by Sastre. ${ }^{32}$ The theatre critic Eric Bentley termed the play 'a political drama of resistance to tyranny, of belief in freedom', although he says that the main freedom it concerns is not political, but rather 'the freedom that comes of finding and realizing the self', which, in Sartre, can be linked to altruism (1946, p. 76). Both for its depiction of the people of Argos, read in the 1940s as a commentary on France under the Vichy government, and for its focus on the killing of a political leader, it was clear that the play could also be read politically in 1960s Spain.

The censors' reports show some of their concerns. Artola mentioned both political and religious grounds for censorship but given that it had already been authorised in Catalan, opted for overall authorization. Elorriaga's report is more interesting: while acknowledging the importance and quality of the play, he pointed to its difficult theme and suggested that the danger lay in the public's interpretation of the play, presumably because of the political circumstances of the times. Indeed, shortly after the application was made, a national state of exception was declared on 24 January 1969 for a period of three months (Decreto-Ley $1 / 1969$, p. 1175). Aragonés was the only censor to address directly the issue of the translator and his comments on Sastre were not flattering. He had gone to the trouble of comparing Pedrolo's Catalan translation to Sastre's version and found some differences in nuance in the language used by Sastre and, overall, deemed it poor. In the end, while it was authorised for over 18s, the authorities were clearly concerned about how it might be staged and specified in the verdict that staging be closely monitored. Interestingly, the play later became part of the regime's showcasing of theatre - and of its own liberalism - in the 1970-71 season and featured as one of the plays in the state-sponsored National Theatre Campaign, which took several plays on a tour of the provinces (See Orden de 30 de septiembre de 1970).

A December 1969 application to stage Les Séquestrés d'Altona in a version by Sastre was made by Manuel Collado at the Merlo-Larrañaga company, for staging at the Teatro Infanta Beatriz in February of $1970 .{ }^{33}$ Although ostensibly about Nazis, it was generally understood in France (Pucciani, 1961) that there was a parallel with the state's actions in Algeria, and a similar resonance obtained in a Spain under a dictatorship in which political opponents were tortured and killed. ${ }^{34}$ Despite this, the censors discussed instead the incestuous relationship between sister and brother, and Frantz's religious language of

\footnotetext{
${ }^{32}$ SIG 73/9689. File 409/68.

${ }^{33}$ SIG 73/9751. File 468/69.

${ }^{34}$ Indeed Sastre's own play, En la red (1960), perhaps inspired by Sartre, depicts a group of freedom fighters struggling to liberate Algeria.
} 
transubstantiation: 'This is my body' ... 'This is my blood', and in the end, perhaps believing - or wishing to believe - that geographical distance would prevent the public from seeing parallels with Spain, approved it for over 18s without cuts. Interestingly, one of the censors, the writer Federico Muelas, praises Sastre's translation: 'Excelente creación de Jean Paul Sartre, vertida pulcramente al castellano' (Excellent creation by Jean Paul Sartre, neatly conveyed into Castilian). ${ }^{35}$

This also fits with the comment of the censor Martínez Ruiz on Sastre's translation of Morts sans sépulture: 'no presenta cambios sustanciales o importantes' (does not contain substantial or important changes). In this particular case, however, the translation of the French text led not to staging in a commercial theatre as desired, but instead saw the play restricted to minority audiences. ${ }^{36}$ The generally faithful translation of the source text is, therefore, only part of the story: the combination of theme, author and translator mean that the work was framed to be read politically and the censors were aware of this.

Yet Alfonso Sastre sometimes took liberties with the source text. One of his most interesting interventions was in his translation of Les troyennes, for staging by Ricardo Salvat and the Adrià Gual Company in $1970 .{ }^{37}$ Sartre had created his version of the Euripides' play in 1965. It not only condemns war but can also be read as critical of the French state's actions in Algeria. In Sastre's version, the implied denunciation is of the Spanish state and the censor Bautista de la Torre's report comments on Sastre's 'refashioning' of the play and he, like the censor Aragonés, recognized Sastre's hand and political mischief in Cassandra's utterance of the word 'generalísimo' (Franco's official appellation), which was not in the French version. Despite this, it was authorised for over $18 \mathrm{~s}$ with the removal of the offending word and clear direction that costume and staging had to reflect the time in which the original play is set (rather than Franco's Spain).

For Alfonso Sastre, as for Jean-Paul Sartre, the theatre was a site of political engagement, and the former's versions of the latter's plays, even when faithful to the source text, are among the best examples of translation as activism in Spain under Franco.

\section{Conclusion}

Given that much of Sartre's theatre can be read as critical of the actions of the French state, his message had ready application in Franco's Spain and a small but important number of

\footnotetext{
${ }^{35}$ SIG 73/9751 File 468/6.

${ }^{36}$ SIG. $73 / 9627$ File $363 / 67$.

${ }^{37}$ SIG 73/9796. File 357/70.
} 
translators and theatre practitioners set out to transpose it to their country. Some, like Pedrolo in Catalonia, wished to promote a language and theatre that had earlier been silenced by the regime; others, like Sastre, aimed to transmit both the silenced truths about the dictatorship and to foreground alternative values or an alternative social order, criticizing the status quo and suggesting that change was necessary. In the case of both of these author-translators, this work allowed them to evade censorship and to continue their communication with their own audiences (and potentially to reach new ones).

Both activist translator and censor stressed the foreignness of the work - the former to suggest freedoms that were absent in Spain; the latter to distance the criticisms from the Spanish situation. One negative consequence was that the regime could make a case for its liberal credentials and dismiss arguments about dictatorship by citing its authorisation of these works, albeit for restricted audiences in teatros de cámara, or, as we saw with Sartre's Les mouches, for inclusion in the regime-sponsored National Theatre Campaign.

Yet several of Jean-Paul Sartre's plays were eventually staged in mainstream, commercial theatres by renowned theatre practitioners, known for their political commitment. Moreover, the authorisation of his theatre, as we saw, coincided with a rise in public opposition to the regime. We can reason, therefore, that the engaged translations of Sartre's theatre that made it to the stage in Spain helped to keep certain political discussions in the public domain and, moreover, fostered solidarity amongst politically-active opponents of the regime, encouraging them in their anti-regime efforts.

We can conclude, therefore, that during the dictatorship, the translation of foreign drama made possible the transmission of alternative ideas and memories; the challenge to the power and identity of the regime; and the evasion of censorship. More broadly and from the perspective of the present day, the analysis of the minority practice of engaged translation enhances our understanding, not only of Spain's theatre history - and the role of translation within it - but also of the interplay between censorship and memory. This analysis suggests that we ought to question how theatre from the period has been understood and remembered and to recognise how memories of cultural activism show us that some Spanish theatre under the dictatorship provided a transnational, provocative and, ultimately hopeful, riposte to the regime's assaults on left-wing culture.

\section{References:}


Abellán, M. L. (1980). Censura y creación literaria en España (1939 - 1976). Madrid: Peninsula.

(1989). Problemas historiográficos en el estudio de la censura literaria del último medio siglo. Revista canadiense de estudios hispánicos, 13 (3), 319-29.

Adorno, T. (1977). Commitment. (Trans. by McDonagh, F.). In F. Jameson (Ed.), Aesthetic and Politics (pp. 177-95). London: New Left Books.

Baker, G. (2003). Pressing Engagement: Sartre's Littérature, Beauvoir's Literature, and the Lingering Uncertainty of Literary Activism. Dalhousie French Studies, 63, 70-85.

Baker, M. (2006). Translation and Conflict: A Narrative Account. London \& New York: Routledge. (2007). Reframing Conflict in Translation. Social Semiotics, 17(2), 151-69.

Bassnett, S. (1998). Still Trapped in the Labyrinth: Further Reflections on Translation and Theatre. In S. Bassnett \& A. Lefevere (Eds.), Constructing Cultures: Essays on Literary Translation (pp. 90-108). Clevedon: Multilingual Matters.

Bentley, E. (1946). Jean-Paul Sartre, Dramatist: The Thinker as Playwright. The Kenyon Review, 8(1), 66-79.

Bondy, F. (1967). Jean-Paul Sartre and Politics. Journal of Contemporary History, 2(2), 2548.

Contat, M. \& Rybalka M.(Eds.) (1974). The Writings of Jean-Paul Sartre. A Bibliographical Life. Vol 1. Trans. R. Mc Cleary. Evanston: Northwestern University Press.

Cox, G. (2016). Existentialism and Excess: The Life and Times of Jean-Paul Sartre. London: Bloomsbury.

De Paco, M. (Ed.) (1993). Alfonso Sastre. Murcia: Universidad de Murcia.

Fernández Torres, A. (Coord.) (1987). Documentos sobre el Teatro Independiente Español. Madrid: CNNTE.

Callen, E. (1996). Catalan Theatrical Life: 1939-1993. In D. George \& J. London (Eds.), Contemporary Catalan Theatre (pp. 19-42). An Introduction. London: Anglo-Catalan

Society. Retrieved from http://www.anglo-catalan.org/downloads/acsopmonographs/issue09.pdf.

Castilla, A. (1999). Diez años de teatro universitario en España y América (1958-1968). In L. García Lorenzo (Ed.), Aproximación al teatro español universitario (TEU) (pp. 235-78). Madrid: CSIC.

Forest, E. (Coord.). (1997). Alfonso Sastre o la ilusión trágica. Hondarribia: Hiru. Fontcuberta i Famadas, J. (2005). Benaventura Vallespinosa. Translation and Cultural 
Revitalisation. In A. Branchadell \& L. M. West (Eds.), Less Translated Languages (pp. 32938). Amsterdam/Philadelphia: John Benjamins.

García Escudero, J. M. (1978). La primera apertura. La larga batalla de la censura en cine y teatro. Diario de un director general. Barcelona: Planeta.

García Lorenzo, L. (1975). El teatro español hoy. Barcelona: Planeta.

García Ruiz, V. (2013). Alta comedia y comedia de evasión: Pemán, Calvo Sotelo, Ruiz Iriarte y otros autores. Alicante: Biblioteca Virtual Miguel de Cervantes. Retrieved from http://www.cervantesvirtual.com/nd/ark:/59851/bmc1c3p7

Gregor, K. (2010). Shakespeare in the Spanish Theatre: 1772 to the Present. London: Continuum.

George, D. \& London, J. (1996). Avant-garde Drama. In D. George \& J. London (Eds.), Contemporary Catalan Theatre. An Introduction (pp.73-101). London: Anglo-Catalan Society.

Gies, D. T. (1975). David and Goliath: The Resolution of Tyranny and Oppression in Two Plays by Alfonso Sastre. Modern Language Studies, 5(2), 94-100.

Godayol, P. (2016). Censorship and the Catalan translations of Jean-Paul Sartre. Perspectives, 24(1), 59-75. . (2018). Las traducciones catalanas de Jean-Paul Sartre. Bulletin hispanique, 120(1), $309-24$.

Goldmann, L. \& MacDonald, S. (Trans.) (1970). The Theatre of Sartre. The Drama Review: TDR, 15(1), 102-119.

Huerta Calvo, J. (2018). Introducción al estudio del Teatro Español Universitario en su primera etapa (1940-1951): una bibliografía crítica. Anales de literatura española, 2930(monograph 19), 13-46.

Larraz, F. (2016). Semblanza de Gonzalo Losada Benítez (1894- 1981). Retrieved from h t t $\mathrm{p}: / / \mathrm{ww}$ w. cervantesvirtual. com/obra/gonzalo-losada-benitez - ma d r i d - 1894---buenos-aires-1981-semblanza/.

London, J. (1997). Reception and Renewal in Modern Spanish Theatre: 1939-1963. MHRA Texts and Dissertations, 45. Cambridge: MHRA.

Martínez-Michel, P. (2003). Censura y represión intelectual en la España franquista: el caso de Alfonso Sastre. Hondarribia: Hiru.

Merino-Álvarez, R. TRACE. TRAnslations Censored. Retrieved from www.ehu.es/trace. Morgan, M. (2013). Politics and Theatre in Twentieth-Century Europe: Imagination and Resistance. New York: Palgrave Macmillan. 
Muñoz Cáliz, B. (2005). El teatro crítico español durante el franquismo, visto por sus censores. Madrid: Fundación Universitaria Española.

O’Connor, P. W. (1966). Government Censorship in the Contemporary Spanish Theatre.

Educational Theatre Journal, 18(4), 443-49.

O'Leary, C. (2004). The Censors' Confusion: (Mis)Interpretations of the Works of Alfonso Sastre. NUI Maynooth Papers in Spanish, Portuguese and Latin American Studies, 9, 1-24. . (2005). The Theatre of Antonio Buero Vallejo: Ideology, Politics and Censorship.

Woodbridge: Tamesis.

Pasquariello, A. (1965-66). Alfonso Sastre, Dramatist in Search of a Stage. The Theatre Annual, 22, 16-23.

Pijuan Vallverdú, A. (2005). Manuel de Pedrolo. Not just a prolific translator. In A.

Branchadell \& L. M. West (Eds.), Less Translated Languages (pp. 339-52).

Amsterdam/Philadelphia: John Benjamins.

Preston, P (1986). The Triumph of Democracy in Spain. London and New York. Methuen.

Pucciani, O. F. (1961). Les Séquestrés d'Altona of Jean-Paul Sartre. The Tulane Drama Review, 5(3), 19-33.

Rodríguez Tejada, S. (2015). The anti-Franco student movement's contribution to the return of democracy in Spain. Espacio, Tiempo y Educación, 2(2), 77-106.

Rundle, C. \& Sturge, K. (2010).Translation and the History of Fascism. In C. Rundle \& K. Sturge (Eds.), Translation under Fascism (pp. 3-12). London: Palgrave.

Salgado, D. (2010, November 28) Francisco Fernández del Riego, intellectual galleguista. El país. Retrieved online from:

https://elpais.com/diario/2010/11/28/necrologicas/1290898801_850215.html.

Santiago Muñoz, Fernando, 'El Pemán franquista', El país, 31 July, 2006, http://elpais.com/diario/2006/07/31/andalucia/1154298128 850215.html

Sanyal, D. (2010). Crabwalk History: Torture, Allegory, and Memory in Sartre. Yale French Studies, 118/119, 52-71.

Sartre, J-P. (1976 [1948]). Qu'est-ce que la literature? Paris: Gallimard. . (1950). Teatro. (Las moscas; A puerta cerrada; Muertos sin sepultura; La mujerzuela respetuosa; Las manos sucias). Trans. by A. Bernárdez. Buenos Aires: Losada. . (1961). Teatro. (Los secuestrados de Altona). Trans. by M. Á. Asturias and B. de Asturias. Buenos Aires: Losada. . (2005). Théâtre complet. Eds. M. Contat, et al. Paris: Gallimard.

Sastre, A. (1956). Drama y sociedad. Madrid: Taurus. 
. (1965). Anatomía del realism. Barcelona: Seix Barral.

(1970). La revolución y la crítica de la cultura. Barcelona: Grijalbo.

Saumell, M. (1996). Performance groups in Catalonia. In D. George \& J. London,

Contemporary Catalan Theatre. An Introduction (pp. 103-128). Sheffield, The Anglo-

Catalan Society.

Stoekl, A. (2003). What the Nazis Saw: 'Les Mouches' in Occupied Paris. SubStance, 32(3. 102), 78-91.

Thompson, M. (2012). The Order of the Visible and the Sayable: Theatre Censorship in Twentieth-Century Spain. Hispanic Research Journal, 13(2), 93-110.

Tymoczko, M. (2007). Enlarging Translation, Empowering Translators. Manchester, St Jerome.

. (2009). Censorship and self-censorship in translation: ethics and ideology, resistance and collusion. In E. Ní Chuilleanáin, C. Ó Cuilleanáin \& D. Parris (Eds.), Translation and Censorship: Patterns of Communication and Interference (pp. 24-45). Dublin: Four Courts Press.

(2010). Translation, Resistance, Activism: An Overview. In M. Tymoczko (Ed.),

Translation, Resistance, Activism (pp. 1-22). Amherst and Boston: University of

Massachusetts Press.

Vandaele, J. (2010). It Was What It Wasn't: Translation and Francoism. In C. Rundle \& K.

Sturge (Eds.), Translation under Fascism (pp. 84-116). London: Palgrave.

Woods, M. (2012). Censoring Translation. Censorship, Theatre and the Politics of

Translation. London: Continuum.

Zatlin, P. (1994). Cross-cultural Approaches to Theatre: The Spanish-French Connection. Metuchen, N.J: Scarecrow Press.

\section{Legislation:}

Orden 15 julio 1939 (Mº. Gobernación). CENSURA. Crea una Sección de Censura encargada de llevarla a cabo. BOE, 211, 553.

Orden 9 febrero 1963 (MIT), por la que se aprueban las 'Normas de censura cinematográfica'. BOE, 58, 3929-30.

Orden 6 febrero 1964 (MIT), por la que se aprueba el Reglamento de Régimen Interior de la Junta de Censura de Obras Teatrales y las Normas de Censura. BOE, 48 (25 February 1964), 2504-06.

Decreto-Ley 1/1969 (Jefatura del Estado), de 24 de enero, por el que se declara el estado de excepción en todo el territorio nacional. $B O E, 22,1175$. 
Orden de 30 de septiembre de 1970 (MIT), por lo que se elena a definitive el fallo provisional del concurso para la 'Campaña Nacional de Teatro 1970-1971'. BOE, 288, 19620. 